\title{
Cytotoxic Effect of Bee (A. mellifera) Venom on Cancer Cell Lines
}

\author{
Sima Khalilifard Borojeni ${ }^{1}$, Hossein Zolfagharian ${ }^{1}$, Mahdi Babaie $^{1,2}$, Iraj Javadi ${ }^{3}$ \\ ${ }^{1}$ Department of Venomous Animals and Antivenom Production, Razi Vaccine and Serum Research Institute, Agricultural Research \\ Education and Extension Organization (AREEO), Karaj, Iran \\ ${ }^{2}$ Young Researchers and Elites Club, Science and Research Branch, Islamic Azad University, Tehran, Iran \\ ${ }^{3}$ Department of Toxicology, Islamic Azad University, Shahreza Branch, Shahreza, Isfahan, Iran
}

Received November 25, 2019

Reviewed November 20, 2020

Accepted November 24, 2020

*Corresponding Author

Hossein Zolfagharian

Department of Venomous Animals and

Antivenom Production, Razi Vaccine and

Serum Research Institute, Agricultural

Research Education and Extension

Organization (AREEO), Karaj, Iran

Tel: +98-026-3457-0038

E-mail: zolfagharianh@yahoo.com
Objectives: Nowadays cancer treatment is an important challenge in the medical world that needs better therapies. Many active secretions produced by insects such as honey bees used to discover new anticancer drugs. Bee venom (BV) has a potent anti inflammatory, anti cancer and tumor effects. The aim of present study is evaluation of anticancer effects induced by Apis mellifera venom (AmV) on cell Lines.

Methods: AmV was selected for study on cancer cell lines. Total protein, molecular weight and $\mathrm{LD}_{50}$ of crude venom were determined. Then, cells were grown in Dulbecco's Modified Eagle medium supplemented with $10 \%$ fetal bovine serum and $1 \%$ antibiotics. The $A_{549}$, HeLa and MDA-MB-231 cell Lines were exposed by different concentration of AmV. The morphology of cells was determined and cell viability was studed by MTT assay. Evaluation of cell death was determined by and DNA fragmentation.

Results: The results from MTT assay showed that $3.125 \mu \mathrm{g} / \mathrm{mL}$ of $\mathrm{A}_{549}, 12.5$ for HeLa and $6.25 \mu \mathrm{g} / \mathrm{mL}$ of MDA-MB-231 killed $50 \%$ of cells $(p<0.05)$. Morphological analysis and the results from hoescht staining and DNA fragmentation indicated that cell death induced by AmV was significantly apoptosis.

Conclusion: The data showed that using lower dosage of AmV during treatment period cause inhibition of proliferation in time and dose dependant manner. Findings indicated that some ingredients of AmV have anticancer effects and with further investigation it can be used in production of anticancer drugs.

Keywords: cancer, bee venom, cell lines, MTT, apoptosis

\section{INTRODUCTION}

Cancer is one of the diseases that is associated with abnormal cell growth and in most cases can spread to other parts of the body and remains as one of the leading causes of mortality worldwide [1]. Estimates are that in 2018, 18.1 million new cases of cancer and 9.6 million deaths occured globally. According to the world health organization (WHO) reports, the number of new cancer cases will increase rapidly in the coming years [2].

Various therapies have been used for treating cancer such as chemotherapy, radiotherapy, immunotherapy and gene therapy [3]. In recent years, biotoxins such as snakes, scorpions and bee venoms have been used as cancer therapeutic agents [4]. In the meantime, bee venom (BV) are very important. BV, like many other complementary medicine approaches, has been used for thousands of years attempting to alleviate a range of diseases [5]. BV have been widely used in traditional medicine to relieve pain and to treat inflammatory diseases. Other potential bee venom-related treatments are currently under investigation [6].

Recently, BV is widely used to treat various cancers [7]. This venom contains various active protein compounds $[8,9]$. BV is a mixture of biologically active compounds such as enzymes, peptides and amines [10]. The main enzyme present is phospholipase $\mathrm{A}_{2}$ and the main peptide is mellitin. Approximately 
$50 \%$ of BV is comprised of melittin, which has a profound neurohormonal and immunological effect on the body [11].

Peptides in BV containing melittin have attracted considerable attention for their potential use in cancer therapy. It seems that melittin, a powerful anticancer peptide might be the better choice than whole BV [12].

Melittin displays strong membrane-perturbing activity, which is responsible for its anti-microbial [13], antiviral [14], antifungal [15], and anticancer [16] activities. When several melittin molecules penetrate into the cell membrane, they break down the phospholipids leading to cell lysis. In fact, this peptide disintegrates the phospholipid and synthetic bilayers $[17,18]$. It has been reported that it can induce apoptosis and has antitumor effects. Melittin can target different cancer cell types such as kidney, liver, lung, prostate, and bladder cancers, as well as breast carcinoma and leukemia [9].

Antitumor compounds induce apoptosis in cancer cells; therefore, apoptosis plays an important role in preventing tumor progression. Consequently, BV can help treat cancer through inducing apoptosis in some cell lines [18].

Due to the disadvantages of the existing therapeutic methods, it is felt more than ever to use new compounds and methods, especially natural compounds, to control and treat cancer. That is why in the present research, cytotoxic effect of AmV on cancer cell lines was investigated.

\section{MATERIALS AND METHODS}

\section{Collection and preparation of AmV}

A. mellifera venom (AmV) was obtained from a beekeeping farm in Ardestan, Isfahan province, Iran. The extracted venom was lyophilized and stored in $-20^{\circ} \mathrm{C}$ until use. In order to prepare a stock solution of the venom, $1 \mathrm{mg}$ of AmV was dissolved in $1 \mathrm{~mL}$ of phosphate-buffered saline (PBS). After vertex, centrifugation $(15,000 \mathrm{~g}, 5 \mathrm{~min})$ was performed at $25^{\circ} \mathrm{C}$. The supernatant filtered through a $0.2 \mu$ membrane filter and stored in darkness at $-40^{\circ} \mathrm{C}$.

\section{Determination of protein concentrations and molecular weight}

Protein concentration of $\mathrm{AmV}$ was determined according to the method described recently [19]. The approximate molecular weight of the AmV was determined by $12 \%$ SDS-PAGE and subsequent staining with coomassie blue [20].

\section{Determination of lethal dose}

An approximate lethal dose $50\left(\mathrm{LD}_{50}\right)$ of the $\mathrm{AmV}$ was determined in $30 \mathrm{NIH}$ mice (18 to $20 \mathrm{~g}$ ). $\mathrm{LD}_{50}$ of $\mathrm{AmV}$ was determined according to the method described recently [19]. Five doses $(1,1.5,2,2.5$ and $3 \mathrm{mg} / \mathrm{kg})$ were injected into two groups of mice for the determination of $\mathrm{LD}_{50}$ of the combination starting from $0 \%$ to $100 \%$ mortality. The percentage of mortality was calculated using the method of Spearman-Karber [21].

\section{Cell culture}

The $\mathrm{A}_{549}$ (ATCC: CCL-185 ${ }^{\mathrm{TM}}$ ), HeLa (ATCC: CCL-2 ${ }^{\mathrm{TM}}$ ) and MDA-MB-231 (ATCC: HTB-26 ${ }^{\mathrm{TM}}$ ) cell Lines were prepared. Cells were cultured in Dulbecco's Modified Eagle (DMEM) medium supplemented with $10 \%$ fetal bovine serum (FBS), Lglutamine and kanamycin/neomycin $(100 \mathrm{U} / \mathrm{mL})$. Cell cultures were then maintained at $37^{\circ} \mathrm{C}$ in a $95 \%$ humidified with $5 \% \mathrm{CO}_{2}$ [22].

\section{Cell viability assay}

To determine the cell number, The $\mathrm{A}_{549}$, HeLa and MDAMB-231 cells were plated in 16 -well plates $\left(5 \times 10^{4}\right.$ cells/well), and subconfluent cells were subsequently treated with AmV (1, 5 , and $10 \mathrm{mg} / \mathrm{mL})$ or melittin $(0.5,1$, and $2.5 \mathrm{mg} / \mathrm{mL})$ for 24,48 , and $72 \mathrm{~h}$. After treatment, cells were trypsinized and pelleted by centrifugation for $5 \mathrm{~min}$ at $200 \mathrm{~g}$, resuspended in PBS $(10 \mathrm{~mL})$, and $0.2 \%$ trypan blue $(0.1 \mathrm{~mL})$ was added to the cancer cell suspension in each of the solutions $(0.9 \mathrm{~mL}$ each). Subsequently, a drop of suspension was placed into a Neubauer chamber and the living cancer cells were counted. Cells that showed signs of staining were considered to be dead, whereas those that excluded trypan blue were considered viable. Each assay was carried out in triplicate [22].

\section{Cytotoxic effect}

AmV cytotoxic effect on $\mathrm{A}_{549}, \mathrm{HeLa}$ and MDA-MB-231 cell Lines, were determined according to MTT assay [9]. The cells were plated in 96-well plates at a density of 40,000 cells/well in $10 \%$ FBS supplemented DMEM. The plates were incubated at $37^{\circ} \mathrm{C}, 5 \% \mathrm{CO}_{2}$ and $95 \%$ humidity for $12 \mathrm{~h}$. The medium 
was then carefully removed and venom concentrations (1.56, $3.12,6.25,12.5,25$ and $50 \mu \mathrm{g} / \mathrm{mL}$ ) was added. Incubation was performed for 24 and $48 \mathrm{~h}$. After incubation, $100 \mu \mathrm{L}$ of MTT reagent $(5 \mathrm{mg} / \mathrm{mL}$ in physiological solution) added to each well in the dark condition and incubation continued for $4 \mathrm{~h}$. After this time, the supernatant was removed and DMSO $(100 \mu \mathrm{L})$ was added to each well to dissolve formazan salt. Absorbance measured at $570 \mathrm{~nm}$ and viability Percent calculated as follows:

Viability of cells $=$ test absorbance $/$ control absorbance $\times 100$

\section{Morphological and apoptosis analysis}

The cells were seeded at density of $5 \times 10^{5}$ cells/well in 12 well plates containing RPMI-1640 supplemented with 10\% FBS and incubated for $12 \mathrm{~h}$. Then the medium was removed, treated with 1, 1.8 and $4 \mu \mathrm{g} / \mathrm{mL} \mathrm{AmV} \mathrm{(diluted} \mathrm{in} \mathrm{FBS} \mathrm{free} \mathrm{medium),}$ and incubation continued for $12 \mathrm{~h}$. The cells were observed by an invert microscope (INV100-FL, BEL-Italy) equipped with phase-contrast lens and finally morphological events compared with untreated cells [9]. Detection of apoptosis was done as described elsewhere [22, 23].

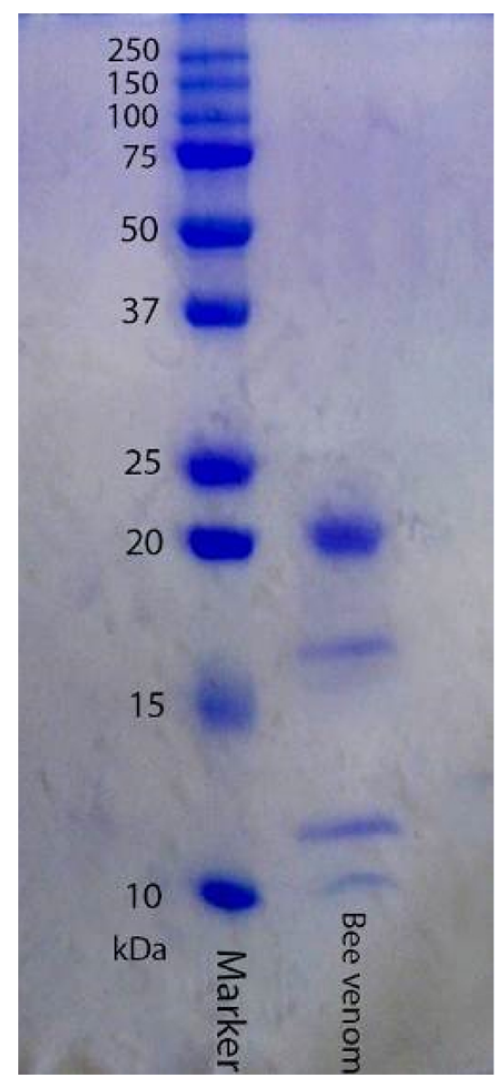

Figure 1. SDS-PAGE of BV.

\section{Data analysis}

Data were analyzed using SPSS software (Version 21). Data are presented as mean \pm SE. A value of $p<0.05$ was considered to be statistically significant.

\section{RESULTS}

\section{Protein concentration, SDS-PAGE of AmV}

The amount of protein in crude AmV solution was $1.48 \mathrm{mg} /$ $\mathrm{mL}$. The molecular weight of $\mathrm{AmV}$ proteins was estimated at a range of $10-22 \mathrm{kDa}$. Crude $\mathrm{AmV}$ is composed four protein bands with molecular weights of $10,12,16$ and $21 \mathrm{kDa}$, respectively (Fig. 1).

\section{Crude AmV LD ${ }_{50}$}

$\mathrm{LD}_{50}$ values using the Probit method was measured (Fig. 2). The AmV LD ${ }_{50}$ was found to be $208 \mu \mathrm{g} /$ mouse.

\section{The cytotoxic effect of AmV using MTT method}

A: $A_{549}$ cells: Cell viability decreased with increasing doses of AmV. This venom inhibited the proliferation of $\mathrm{A}_{549}$, MDAMB-231 and HeLa cell lines in a different concentration of $\mathrm{AmV}$. $\mathrm{IC}_{50}$ (The half maximal inhibitory concentration of AmV) in 24 , and $48 \mathrm{~h}$ were 3.125 and $2.5 \mu \mathrm{g} / \mathrm{mL}\left(\mathrm{A}_{549}\right), 6.25$ and 3.125 $\mu \mathrm{g} / \mathrm{mL}$ (MDA-MB-231) and 12.5 and $6.25 \mu \mathrm{g} / \mathrm{mL}$ (HeLa) re-

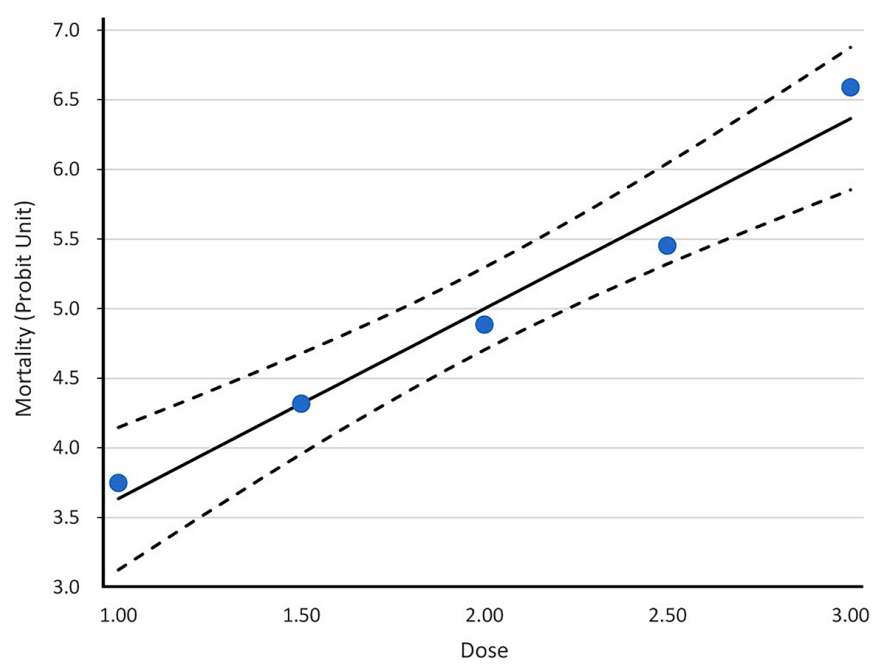

Figure 2. $\mathrm{LD}_{50}$ values using the Probit method. 
spectively. The results of cytotoxic effect for $\mathrm{A}_{549}, \mathrm{MDA}-\mathrm{MB}-231$ and HeLa cell lines are shown in Table 1 and Fig. 3.

\section{Morphological and apoptosis analysis}

A significant difference in morphology between $\mathrm{A}_{549}$, MDAMB-231 and HeLa cells treated with AmV and control cells was observed (Figs. 4-9). Cell shrinkage, irregularity in cellular shape, cellular detachment and serious damage to cell membrane were observed in the AmV-treated cultures, but not in the control.

\section{DISCUSSION}

Old texts show that for years physicians used animal venom to treat diseases. Extensive studies on inhibition of tumor cell proliferation and metastasis as well as induction of apoptosis by $\mathrm{BV}$ give promise of more effective treatment of human tumor types. The results of the present study showed that treatment

Table 1. $A_{549}$ viability with different concentrations of AmV using MTT method

\begin{tabular}{|c|c|c|c|}
\hline Cell lines & $\begin{array}{l}\text { Concentrations } \\
\text { of } A m V(\mu \mathrm{g} / \mathrm{mL})\end{array}$ & $\begin{array}{l}\text { Cell viability (\%), } \\
\qquad 24 \mathrm{~h}\end{array}$ & $\begin{array}{c}\text { Cell viability (\%), } \\
48 \mathrm{~h}\end{array}$ \\
\hline \multirow[t]{7}{*}{$A_{549}$} & Control & $100 \pm 0$ & $100 \pm 0$ \\
\hline & 1.56 & $82.8 \pm 0.015$ & $59.1 \pm 0.005$ \\
\hline & 3.125 & $56.0 \pm 0.015$ & $42.7 \pm 0.004$ \\
\hline & 6.25 & $37.5 \pm 0.011$ & $23.0 \pm 0.004$ \\
\hline & 12.5 & $23.1 \pm 0.009$ & $17.3 \pm 0.004$ \\
\hline & 25 & $17.1 \pm 0.004$ & $14.5 \pm 0.004$ \\
\hline & 50 & $14.8 \pm 0$ & $11.2 \pm 0.007$ \\
\hline \multirow[t]{7}{*}{ MDA-MB-231 cells } & Control & $100 \pm 0$ & $100 \pm 0$ \\
\hline & 1.56 & $78.0 \pm 0.039$ & $62.0 \pm 0.006$ \\
\hline & 3.125 & $65.8 \pm 0.016$ & $52.2 \pm 0.010$ \\
\hline & 6.25 & $49.6 \pm 0.019$ & $39.2 \pm 0.010$ \\
\hline & 12.5 & $35.4 \pm 0.019$ & $26.1 \pm 0.010$ \\
\hline & 25 & $30.3 \pm 0.012$ & $22.8 \pm 0.006$ \\
\hline & 50 & $21.9 \pm 0.007$ & $13.7 \pm 0.006$ \\
\hline \multirow[t]{7}{*}{ HeLa } & Control & $100 \pm 0$ & $100 \pm 0$ \\
\hline & 1.56 & $86.3 \pm 0.015$ & $70.0 \pm 0.005$ \\
\hline & 3.125 & $71.7 \pm 0.015$ & $62.3 \pm 0.004$ \\
\hline & 6.25 & $63.2 \pm 0.011$ & $46.1 \pm 0.004$ \\
\hline & 12.5 & $41.8 \pm 0.009$ & $35.0 \pm 0.004$ \\
\hline & 25 & $30.7 \pm 0.004$ & $27.3 \pm 0.004$ \\
\hline & 50 & $18.8 \pm 0$ & $18.8 \pm 0.007$ \\
\hline
\end{tabular}

of three cell lines with different concentrations of BV inhibited proliferation of the cells and induced apoptosis in a dose- and time-dependent manner. This dependence means that increasing melittin concentration and treatment duration can improve inhibition of cell growth [24].

The highest death cell was observed in $\mathrm{A}_{549}$ cell line treated with $\mathrm{BV}$, while the lowest one was occurred with HeLa cell line. The results of this study were consistent with El-Bassiony et al [25]. Thier results indicated that the studied BV can be used as effective anticancer agent.

Morphological examination of cells with an inverted microscope revealed a major feature of apoptotic cells, i.e. the condensed nucleus, and flow cytometry proved that BV induced cell death through apoptosis. In agreement with these results, Jang et al. reported that BV was capable of inducing apoptosis and inhibiting cyclooxygenase (COX-2) expression in the human lung cancer cell line NCI-H1299. They showed that a certain concentration of BV was able to fragment DNA, following activation of endonucleases, and to induce apoptosis-related morphological changes [26].

Mohseni et al. examined the effects of BV on normal human lymphocytes and the human HL-60 leukemia cell line. They reported that whole BV had selective cytotoxic effects on normal and cancer cells. Using this compound in a dose-dependent manner for up to 24 hours reduced the survival of HL-60 cells. Similar effects were observed in the present study [27].

Tu et al. investigated the effects of BV on the human melanoma cell line A2058. They acknowledged that BV, in a calcium-dependent and caspase-independent pathway, induced apoptosis in this cell line, whereas it did not have such effect on normal Detroit 551 human fibroblast cells [28].

In study of Liu et al., the $\mathrm{IC}_{50}$ for melittin on MHCC97L cells, MHCC97H cells, Rac1-DA-transfected MHCC97H cells and Rac1-DN-transfected MHCC97H cells were 9.24, 4.06, 3.83 and $25.69 \mu \mathrm{g} / \mathrm{mL}$ respectively [29]. These studies reported the toxicity of melittin on higher concentration but in the present study, MTT assay showed that melittin kills cancerous cells at $\mathrm{IC}_{50}$ of 3.125 and $2.5 \mu \mathrm{g} / \mathrm{mL}\left(\mathrm{A}_{549}\right), 6.25$ and $3.125 \mu \mathrm{g} / \mathrm{mL}$ (MDA-MB-231) and 12.5 and $6.25 \mu \mathrm{g} / \mathrm{mL}$ (HeLa) during 24, and $48 \mathrm{~h}$ respectively. Morphological effects of melittin on HeLa cells observed at $\mathrm{IC}_{50}$ concentration. Morphological alterations increased with increasing in melittin concentration and were in accordance to MTT results.

It is noteworthy that some studies have proved that melittin has hemolytic activity $[9,30]$. Therefore, one can say that he- 

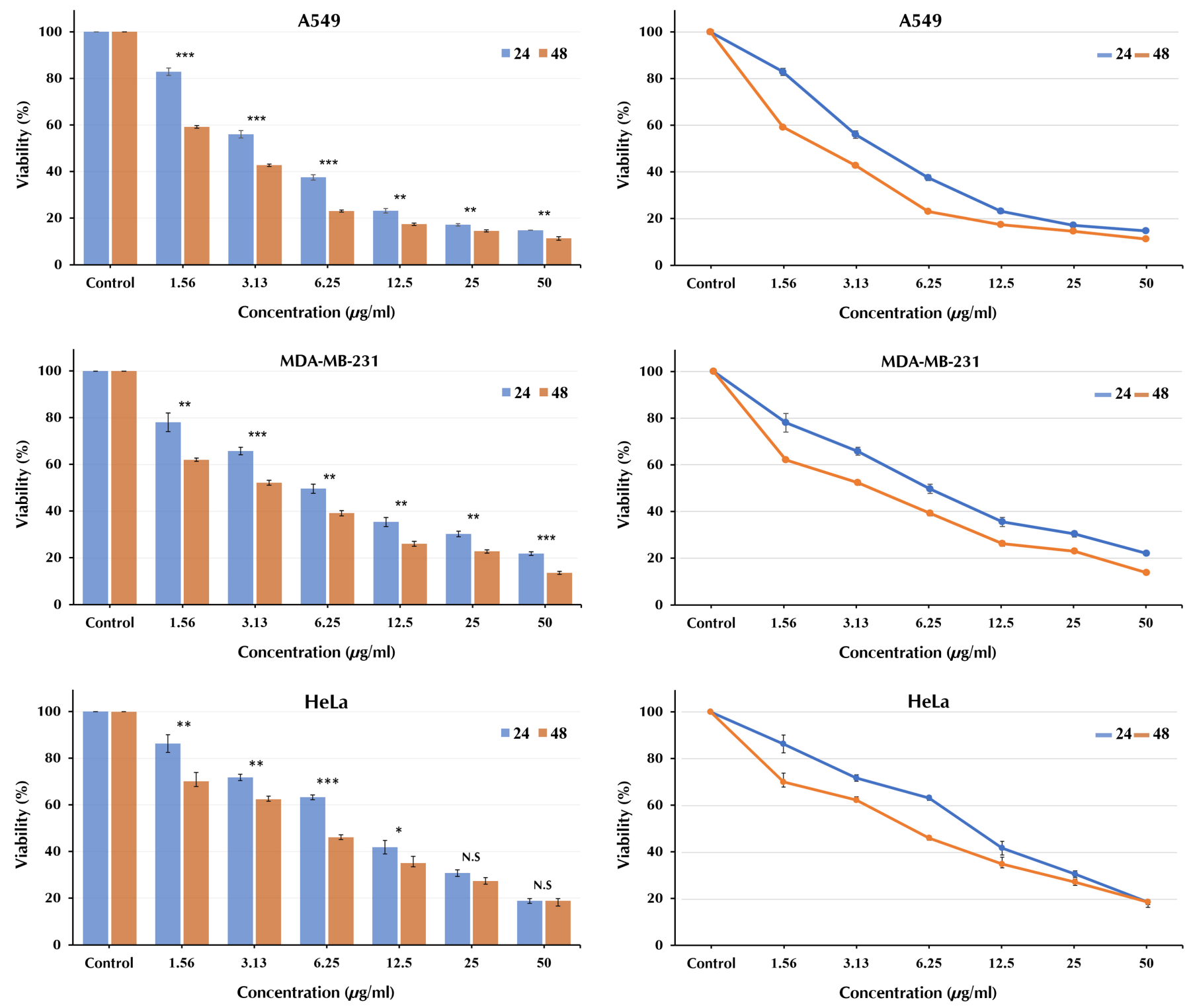

Figure 3. $A_{549}, M D A-M B-231$ and HeLa viability with different concentrations of AmV using MTT method (Mean $\pm S E M, * * * p<0.001$ ).
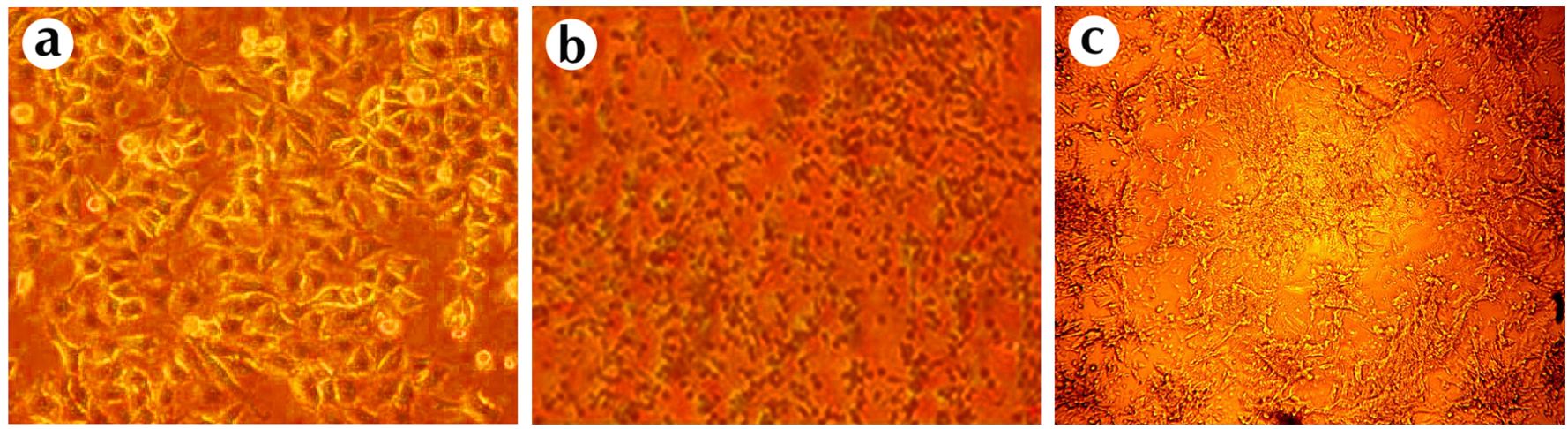

Figure 4. $A_{549}$ cell morphology treated with AmV. (A) Control; (B) 3.125; (C) $12.5 \mu \mathrm{g} / \mathrm{mL}$ of AmV. 

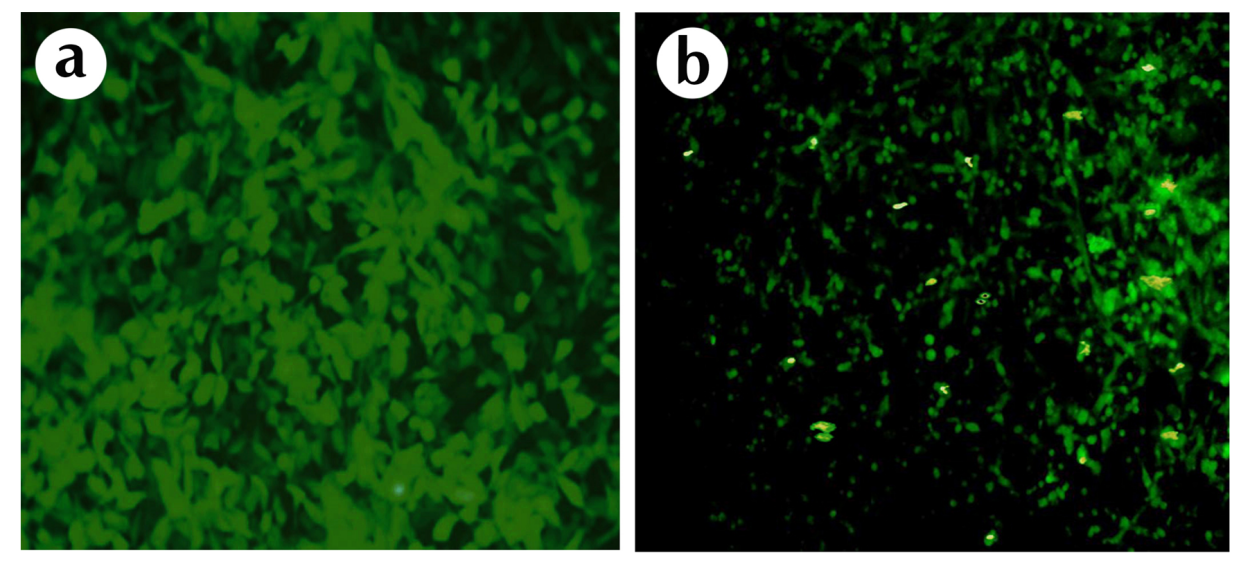

Figure 5. $A_{549}$ cell morphology treated with AmV. (A) Control; (B) $3.125 \mu \mathrm{g} / \mathrm{mL}$ of AmV.
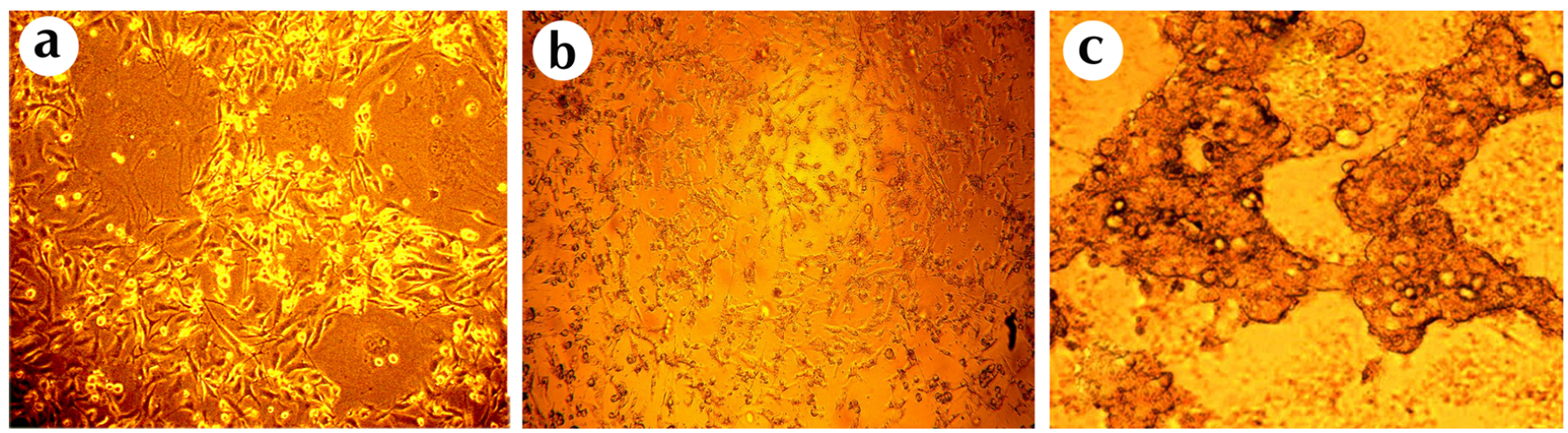

Figure 6. MDA-MB-231 cell morphology treated with AmV. (A) Control; (B) 6.25; (C) $12.5 \mu \mathrm{g} / \mathrm{mL}$ of AmV.
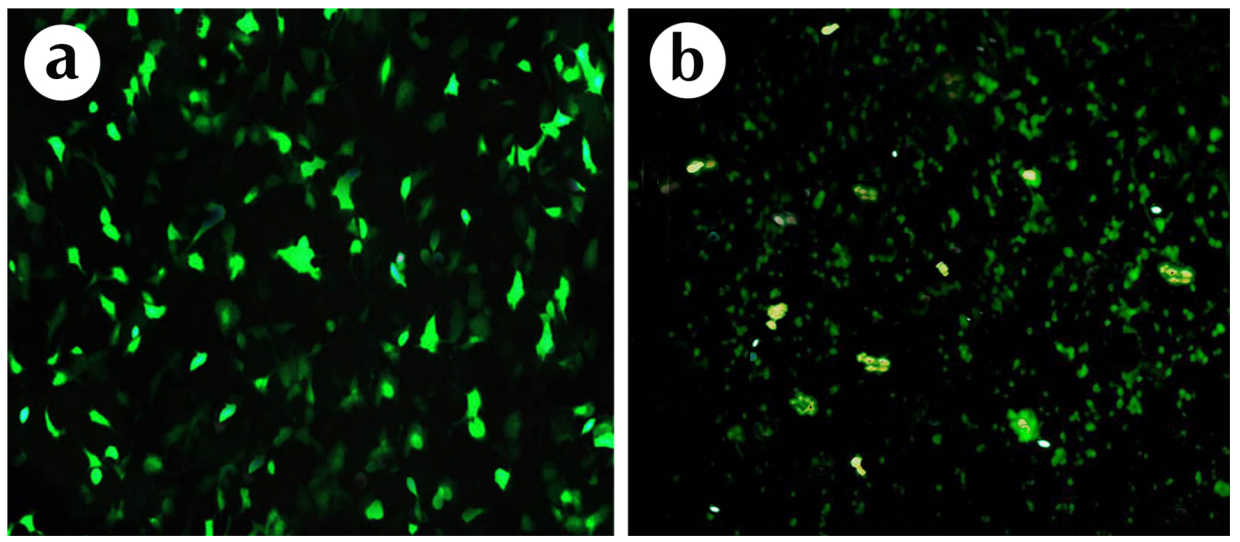

Figure 7. MDA-MB-231 cell morphology treated with AmV. (A) Control; (B) 6.25 $\mu \mathrm{g} / \mathrm{mL}$ of AmV.

molytic activity of melittin is the main obstacle to its use in cancer treatment. Consequently, when designing cancer treatment using melittin, it should be taken into consideration that introduction of melittin into the bloodstream can damage red blood cells. Therefore, it may be more appropriate to treat cancer using melittin through gene therapy (transfer of the melittin gene to cancer cells) or by specific delivery of melittin to cancer cells (for example, use of liposomes as a melittin delivery vehicle).
Most of the drugs used in chemotherapy induce apoptosis in cancer cells and, according to the above reports, BV (and especially melittin) seems to be an appropriate option for cancer treatment. Finally, it must be said that the use of BV, which has fewer side effects than chemical drugs, will cause a revolution in the human struggle against cancer. 

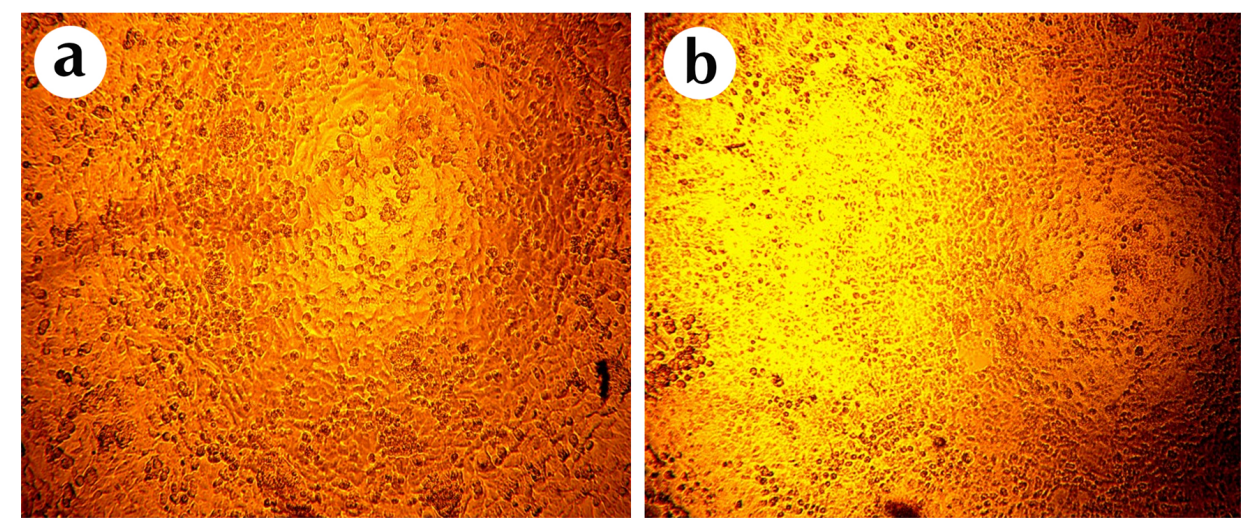

Figure 8. HeLa cell morphology treated with AmV. (A) Control; (B) $12.5 \mu \mathrm{g} / \mathrm{mL}$ of AmV.
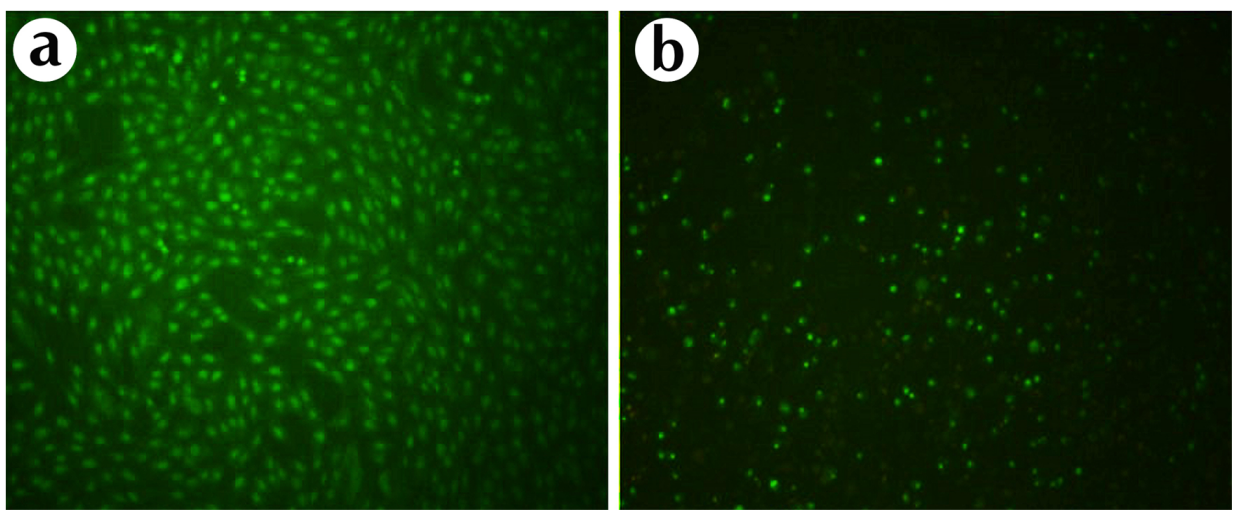

Figure 9. HeLa cell morphology treated with AmV. (A) Control; (B) $12.5 \mu \mathrm{g} / \mathrm{mL}$ of AmV.

\section{CONCLUSION}

Our results provide evidence that BV and its main constituents, especially melittin, may be developed as potential therapeutic agents for cancer metastasis. We assessed that BV as a natural product has cytotoxic effects on the $\mathrm{A}_{549}$, HeLa and MDA-MB-231 cell Lines. It will be an excellent perspective to innovate approaches to prevent and treat some features of cancer.

\section{CONFLICT OF INTEREST}

The authors declare that there are no conflict of interest.

\section{ORCID}

Sima Khalilifard Borojeni, https://orcid.org/0000-0002-0010-9896 Hossein Zolfagharian, https://orcid.org/0000-0002-8093-2400 Mahdi Babaie, https://orcid.org/0000-0001-8366-5929 Iraj Javadi, https://orcid.org/0000-0001-8635-1554

\section{REFERENCES}

1. Hassanpour SH, Dehghani M. Review of cancer from perspective of molecular. J Cancer Res Pract. 2017;4(4):127-9.

2. Siegel RL, Miller KD, Jemal A. Cancer statistics, 2019. CA Cancer J Clin. 2019;69(1):7-34.

3. Pal P, Roy S, Chattopadhyay S, Pal TK. Medicinal value of animal venom for treatment of cancer in humans- a review. World Sci News. 2015;22:128-44.

4. Chaisakul J, Hodgson WC, Kuruppu S, Prasongsook N. Effects of animal venoms and toxins on hallmarks of cancer. J Cancer. 2016;7(11):1571-8.

5. Chen J, Lariviere WR. The nociceptive and anti-nociceptive effects of bee venom injection and therapy: a double-edged sword. Prog Neurobiol. 2010;92(2):151-83.

6. Son DJ, Lee JW, Lee YH, Song HS, Lee CK, Hong JT. Therapeutic application of anti-arthritis, pain-releasing, and anti-cancer effects of bee venom and its constituent compounds. Pharmacol Ther. 2007;115(2):246-70.

7. Oršolić N. Bee venom in cancer therapy. Cancer Metastasis Rev. 2012;31(1-2):173-94.

8. Zolfagharian H, Mohajeri M, Babaie M. Honey bee venom (Apis mellifera) contains anticoagulation factors and increases the 
blood-clotting time. J Pharmacopuncture. 2015;18(4):7-11.

9. Zarrinnahad H, Mahmoodzadeh A, Hamidi MP, Mahdavi M, Moradi A, Bagheri KP, et al. Apoptotic effect of melittin purified from Iranian honey bee venom on human cervical cancer HeLa cell line. Int J Pept Res Ther. 2018;24(4):563-70.

10. Hossen MS, Shapla UM, Gan SH, Khalil MI. Impact of bee venom enzymes on diseases and immune responses. Molecules. 2016;22(1):25.

11. Chen J, Guan SM, Sun W, Fu H. Melittin, the major pain-producing substance of bee venom. Neurosci Bull. 2016;32(3):26572.

12. Zhang SF, Chen Z. Melittin exerts an antitumor effect on nonsmall cell lung cancer cells. Mol Med Rep. 2017;16(3):3581-6.

13. Zolfagharian H, Mohajeri M, Babaie M. Bee venom (Apis Mellifera) an effective potential alternative to gentamicin for specific bacteria strains: bee venom an effective potential for bacteria. J Pharmacopuncture. 2016;19(3):225-30.

14. Uddin MB, Lee BH, Nikapitiya C, Kim JH, Kim TH, Lee HC, et al. Inhibitory effects of bee venom and its components against viruses in vitro and in vivo. J Microbiol. 2016;54(12):853-66.

15. Park J, Kwon O, An HJ, Park KK. Antifungal effects of bee venom components on Trichophyton rubrum: a novel approach of bee venom study for possible emerging antifungal agent. Ann Dermatol. 2018;30(2):202-10.

16. Gajski G, Garaj-Vrhovac V. Melittin: a lytic peptide with anticancer properties. Environ Toxicol Pharmacol. 2013;36(2):697705.

17. Jamasbi E, Mularski A, Separovic F. Model membrane and cell studies of antimicrobial activity of melittin analogues. Curr Top Med Chem. 2016;16(1):40-5.

18. Wang C, Chen T, Zhang N, Yang M, Li B, Lü X, et al. Melittin, a major component of bee venom, sensitizes human hepatocellular carcinoma cells to tumor necrosis factor-related apoptosisinducing ligand (TRAIL)-induced apoptosis by activating CaMKII-TAK1-JNK/p38 and inhibiting IkappaBalpha kinaseNFkappaB. J Biol Chem. 2009;284(6):3804-13.

19. Babaie M, Zolfagharian H, Zolfaghari M, Jamili S. Biochemical, hematological effects and complications of Pseudosynanceia melanostigma envenoming. J Pharmacopuncture. 2019;22(3): 140-6.

20. Babaie M, Ghaem panah A, Mehrabi Z, Mollaei A, Borojeni SK.
Partial purification and characterization of antimicrobial effects from snake (Echis carinatus), scorpion (Mesosobuthus epues) and bee (Apis mellifera) venoms. Iran J Med Microbiol. 2020; 14(5):460-77.

21. Salmanizadeh $H$, Babaie $M$, Zolfagharian $H$. In vivo evaluation of homeostatic effects of Echis carinatus snake venom in Iran. J Venom Anim Toxins Incl Trop Dis. 2013;19(1):3.

22. Park MH, Choi MS, Kwak DH, Oh KW, Yoon DY, Han SB, et al. Anti-cancer effect of bee venom in prostate cancer cells through activation of caspase pathway via inactivation of NF- $\kappa$ B. Prostate. 2011;71(8):801-12.

23. Son DJ, Ha SJ, Song HS, Lim Y, Yun YP, Lee JW, et al. Melittin inhibits vascular smooth muscle cell proliferation through induction of apoptosis via suppression of nuclear factor-kappaB and Akt activation and enhancement of apoptotic protein expression. J Pharmacol Exp Ther. 2006;317(2):627-34.

24. de Souza JM, Goncalves BDC, Gomez MV, Vieira LB, Ribeiro FM. Animal toxins as therapeutic tools to treat neurodegenerative diseases. Front Pharmacol. 2018;9:145.

25. El-Bassiony MN, Mahfouz HM, Hussein AS, El-Hamamy MM, Abdel Daim MM, Bufo SA. Effect of honey bee venom on cancer in rats model. J Entomol. 2016;13(3):72-83.

26. Jang MH, Shin MC, Lim S, Han SM, Park HJ, Shin I, et al. Bee venom induces apoptosis and inhibits expression of cyclooxygenase-2 mRNA in human lung cancer cell line NCI-H1299. J Pharmacol Sci. 2003;91(2):95-104.

27. Mohseni-Kouchesfahani H, Nabioni M, Khosravi Z, Rahimi M. Honey bee venom combined with 1,25-dihydroxyvitamin D3as a highly efficient inducer of differentiation in human acute myeloid leukemia cells. J Cancer Res Ther. 2017;13(3):544-9.

28. Tu WC, Wu CC, Hsieh HL, Chen CY, Hsu SL. Honeybee venom induces calcium-dependent but caspase-independent apoptotic cell death in human melanoma A2058 cells. Toxicon. 2008;52(2): 318-29.

29. Liu S, Yu M, He Y, Xiao L, Wang F, Song C, et al. Melittin prevents liver cancer cell metastasis through inhibition of the Rac1dependent pathway. Hepatology. 2008;47(6):1964-73.

30. Babaie M, Ghaempanah A. Evaluation of hemolytic activity and biochemical properties of Apis mellifera bee venom on $\mathrm{NIH}$ laboratory mice. J Neyshabur Univ Med Sci. 2020;8(3):23-34. 